\title{
THE ASSESSMENT OF THE MANAGEMENT CONTROL SYSTEM IN A LOCAL GOVERNMENT UNIT
}

\author{
Elżbieta PALIGA ${ }^{1}$, Krystyna LISIECKA $^{* 2}$ \\ ${ }^{1}$ Uniwersytet Ekonomiczny w Katowicach, Komitet Naukowy Dyscypliny Nauki o Zarządzaniu i Jakości, \\ Katowice; erob@poczta.fm, ORCID: 0000-0003-3851-3779 \\ ${ }^{2}$ Górnośląska Wyższa Szkoła Handlowa im. W. Korfantego w Katowicach, krystyna.lisiecka@gwsh.pl, \\ ORCID: 0000-0001-5061-5757 \\ * Correspondence author
}

Purpose: The purpose of the research is to form an integrated evaluation of the management control in a local government unit and demonstration of the benefits of successful and effective management of the unit by implementation of the designed method of evaluation. This paper attempts to design an integrated evaluation of management control in a local government unit and demonstrate the benefits of the successful and effective management of the unit by implementation of the designed method of evaluation.

Methodology: The results presented in the paper are a result of research on the improvement of management control in local government units. The methods implemented in the study included: data analysis, a case study and a questionnaire, as well as the results of previous research and management control reports.

Findings: The presented process of integrated assessment of management control will contribute to performing an analysis of the whole organisation and its subordinate units. Moreover, the role of the processes and organisational procedures, which contribute to the adjustment to change management in an organisation, have an impact on improving the efficiency of management control. The advantages of applying the model of integrated assessment of management control include, among others, increasing the awareness and responsibility of the managers and employees for the functioning of management control, minimisation of the time and costs of gathering data and standard method of the management control assessment in local government units.

Practical implications: The paper concludes that applying the model of integrated assessment of management control enables one to assess the management control of local government units, as well as their subordinate units, in all areas of management. The presented process of integrated assessment of management control will contribute to performing an analysis of the whole organisation and its subordinate units. Moreover, the role of the processes and organisational procedures, which contribute to the adjustment to change management in an organisation, have an impact on improving the efficiency of management control. The advantages of applying the model of integrated assessment of management control include, among others, increasing the awareness and responsibility of the managers and employees for the functioning of management control, minimisation of the time and costs of gathering data and standard method of the management control assessment in local government units. 
Keywords: management control, public administration, internal audit, public management.

Category of the paper: research paper.

\section{Introduction}

In 2009, management control was introduced to Polish public administration as a part of the public finance reform ${ }^{1}$. In the opinion of experts (Marcinkowski, 2010; Szostak, 2011; Szpor, n.d.), the ratio legis of the implemented solution was the intention of introducing changes in public administration and transforming it from "law application culture" to "resultsoriented culture".

Although management control has been present in public administration for ten years, local government units are still undergoing the process of developing management control through various assessment tools and methods. The combination of the words 'control' and 'management' itself results in divergences between the definitions of management control proposed by scholars and the Public Finance Act.

Management sciences define management control as one of the elements of the management system; whereas, following the definition provided by legal acts, management control is, in other words, a system of management in public administration. Due to its complexity, management control gathers all the activities which are included in the PDSA model, i.e. planning, organising, leading, controlling and improving the activities of the unit. According to Lisiecka (2012, p. 4), management control is a set of systematic activities, the aim of which is to establish standards and measures of effectiveness for the planned goals, design information feedback, compare actual effectiveness with accepted measures, establish deviations and take corrective or preventive actions in order to ensure appropriate resource utilisation. For Klim (2018, p. 113), management control is a tool, the aim of which is to facilitate the activities of the units of the public finance sector. Nowak (2003, p. 266), on the other hand, defines management control as a process, the goal of which is to check whether a particular unit works in accordance with the established plan of activities and achieves the assumed results.

The activities of the units of the public finance sector are determined by the expectations, values and internal and external relations of the local community, which undoubtedly influence the system of modern management. Remaining open to new solutions creates favourable conditions for adjusting the activities of the units to actual public needs.

\footnotetext{
${ }^{1}$ The Public Finance Act of 27 August 2009 introduced the obligation of providing management control in units of the public finance sector, including local government units.
} 
The correlation between the goals of public organisations and communities is marked by:

- some attributes of those goals (justice and social responsibility),

- being oriented towards achieving more goals,

- non-equivalence of the goals, which is a result of satisfying the needs of different stakeholders at the same time (Gawroński, 2010, p. 23).

Management control gathers all the activities of both a given organisation (1st level of management control) and its subordinate units (2nd level of management control). The author of the paper believes that the process of management control should include both levels.

This paper attempts to design an integrated evaluation of management control in a local government unit and demonstrate the benefits of the successful and effective management of the unit by implementation of the designed method of evaluation.

The results demonstrated in the paper are based on research on the improvement of management control in local government units. The research included the process of management control in a local government unit. The methods implemented in the study included: data analysis, a case study and a questionnaire, as well as the results of previous research and management control reports issued by Poland's Ministry of Finance, Poland's Supreme Audit Office (Najwyższa Izba Kontroli) and the Regional Chamber of Audit (Regionalna Izba Obrachunkowa).

The research allowed the author to propose the thesis that dynamic development of tools and techniques supporting the evaluation of management control forces the implementation of integrated evaluation of management control that should include its two levels.

\section{The role of management control in the management of local government units}

The aim of management control is to ensure:

1. Conformity of activities with legal provisions and internal procedures,

2. Efficiency and effectiveness of activities,

3. Credibility of reports,

4. Protection of resources,

5. Obedience and promotion of rules of professional conduct,

6. Efficiency and effectiveness of information flow,

7. Risk management ${ }^{2}$.

\footnotetext{
${ }^{2}$ Announcement No 23 of the Minister of Finance of $16^{\text {th }}$ December 2009 on Management Control Standards for the public finance sector (Journal of Laws No.157, item. 1240)
} 
Managing the units of public administration and other activities which are the subject of management at a particular managerial position refers to the whole spectrum of activities, from planning to implementation. The solutions provided by the Public Finance Act of 2009 demonstrate the constant need for changes in order to obtain effective and successful management of public administration.

Control management is a process, the aim of which is to ensure that the resources are utilised in a way that will ensure successful and effective completion of the goals of the organisation. Dąbrowski (2017), after Anthony (1965), Ouchi (1979) and Flamholtz (1983), adds that control management should facilitate the cooperation between employees and organisational units.

According to the Audit Department of the Public Finance Sector, management control aims at "...constant facilitation of management, which results in increasing the efficiency and effectiveness of particular units of the public finance sector..." (p. 16). This refers to the statement that management control in local government units functions at two levels: 1) at the level of a local government unit; 2) at the level of subordinate units. This is why the evaluation of management control should not only include the local government, but also other subordinate units.

An internal audit aims at assessing the adequacy, efficiency and effectiveness of management control. All the activities ensure the condition of management control, which, as Cushman and King (1995) agree upon ${ }^{3}$, displays the flexibility and speed of the organisation.

\section{The concept of integrated management control in a local government unit}

When analysing management control, one may notice that it refers to the $3 \mathrm{E}$ principle, namely:

- Effective (deliberate and efficient),

- Economical (profitable, frugal),

- Ethical (in conformity with established values).

All the criteria for management control are included in management control standards; however, there exist no uniform guidelines for management control in public administration. In 2012, Poland's Minister of Finance announced detailed provisions for the sector of public finance in the field of planning and risk management. These provisions are one of the fields of standards for management control.

\footnotetext{
${ }^{3}$ Although Cushman and King (1995) refer to companies only, their postulates might, in my opinion, be applied to the activities of a local government.
} 
According to the standards for management control, the Minister of Finance determined:

1. Internal environment

Internal environment is the basis for all organisations. It includes four standards: observing ethical values, professional competences, organisation structure and delegating entitlements. Observing ethical values refers to the issues of observing, by public administration employees, legal regulations, socially accepted norms, ethical principles and the organisational culture.

2. Risk management

The field of goals and risk management includes the following standards: mission, establishing goals and tasks, task monitoring and accomplishment, risk identification, risk analysis and risk response. Risk management should be performed by management and other managerial employees. The sources of risk should be identified, and the whole process should be systematic. The process of risk identification consists of both internal and external factors.

According to Krasnodomska (2012), integrated reporting influences risk management more effectively (pp. 101-110). Similarly, Remlein (2015) states that organisations which derive benefits need risk identification, which will refer to social responsibility. This should influence better understanding of the changes and influences exerted by the group on the surrounding (pp. 149-166).

3. Control mechanisms

Management control mechanisms include: management control recording, supervision, continuity of activities, resource protection, detailed control mechanisms of financial and administrative operations and control mechanisms of IT systems. Basic documents for management control include: internal procedures, instructions, guidelines and other documents which describe the scope of duties, responsibilities and entitlements of the employees.

4. Information and communication

Information and communications include: current information, internal communication, monitoring and assessment, monitoring of the management control system, selfassessment, internal audit and control management condition assurance. The flow of appropriate, current, reliable and complete information is crucial for the unit. Both internal and external flows of information should be efficient, with the implementation of appropriate tools of communication. 
5. Monitoring and assessment

The monitoring of management control should be performed systematically. When it comes to a unit, the self-assessment should be performed at minimum once per year. In certain cases, units are obliged to perform an internal audit. The results of the monitoring function as the source of information for the unit's supervisor about the condition of management control ${ }^{4}$. Monitoring and management control assessment are the foundations for designing the process of management control assessment.

Mituś (2017) points out that “....it would be legitimate to consider introducing a catalogue of basic activities (duties) to the public finance act. The catalogue should cover all the activities (duties) which should be taken, monitored or controlled in order to ensure appropriate accomplishment of goals and tasks in a public finance sector unit. Such a catalogue would be legitimate in the context of the responsibility of the unit's supervisor regarding non-performance or improper performance of the management control responsibilities. Non-existence of such scope of activities/responsibilities puts the supervisor of a public finance sector unit in a disadvantageous legal position..." (ibid., pp. 11-12).

Taking into consideration the framework of management control, the author believes that integrated assessment of management control is a management process which is designed in order to achieve goals by the organisation through the assessment of its various components: internal environment, risk assessment, control mechanism assessment, information and communication and, finally, monitoring.

Management control also refers to subordinate units. For this purpose, Figure 1 demonstrates a model of integrated management control assessment in which the units of local government are treated as a collection of logically interrelated units. An internal audit plays a key role in the management control assessment; its results offer added value for the organisation.

\begin{tabular}{|c|c|c|c|c|c|}
\hline \multicolumn{5}{|c|}{ Strategic management - determining mission, vision, goals and tasks } & \multirow{4}{*}{$\begin{array}{c}\text { Internal } \\
\text { control - } \\
\text { Integration } \\
\text { of strategic } \\
\text { and } \\
\text { operational } \\
\text { activities }\end{array}$} \\
\hline $\begin{array}{l}\text { Strategic } \\
\text { objectives }\end{array}$ & Strategic tasks & $\begin{array}{l}\text { The stage of } \\
\text { implementation } \\
\text { of strategic tasks }\end{array}$ & $\begin{array}{l}\text { Risk analysis of } \\
\text { strategic task } \\
\text { implementation }\end{array}$ & $\begin{array}{l}\text { Measures taken } \\
\text { after completing } \\
\text { the strategic } \\
\text { tasks }\end{array}$ & \\
\hline \multicolumn{5}{|c|}{ Operations management - determining objectives and tasks related to strategic objectives } & \\
\hline $\begin{array}{l}\text { Organisational } \\
\text { structure }\end{array}$ & $\begin{array}{l}\text { Operational } \\
\text { tasks }\end{array}$ & $\begin{array}{l}\text { The stage of } \\
\text { implementation } \\
\text { of operational } \\
\text { tasks }\end{array}$ & $\begin{array}{l}\text { Risk analysis of } \\
\text { operational } \\
\text { tasks }\end{array}$ & $\begin{array}{l}\text { Measures taken } \\
\text { after completing } \\
\text { the operational } \\
\text { tasks }\end{array}$ & \\
\hline
\end{tabular}

Added value - assessment of management control undertaken by the internal audit in the field of management control standards at the I and II level.

Figure 1. The concept of the integrated assessment of management control with the use of a value chain. Source: own study.

\footnotetext{
${ }^{4}$ Ministry of Finance, Management control in the public finance sector. The essence, legal regulations and environment. Knowledge compendium (version 1.0)..., op. cit., s. 50-64.
} 


\section{Previous research}

The results of the research conducted by Bielińska-Dusza (2011) among 137 units of the private and public sector indicate that both supervisors and internal auditors described the usefulness of an internal audit at average level (ibidem, p. 64).

In 2011, the Supreme Audit Office (Najwyższa Izba Kontroli) attempted to assess the functioning of management control in local government units. The results of the control performed in 20 districts (Polish gmina) demonstrated that management control did not meet certain standards of management control, especially those referring to risk management. The results of the research indicated the absence of any methodology of uniform assessment of management control.

The results of the 2016 research on the assessment of the functioning of management control conducted by the Ministry of Finance in 1,255 local government units demonstrated that the implementation of management control led to introducing new procedures, which resulted in the increase of employee duties and excessive bureaucracy.

Between 2010 and 2014, Dyczkowska \& Dyczkowski (2014) researched the organisation of management control with reference to the effectiveness of the implementation of management control on the decision-making processes among executives of the public sector. The results indicate certain communication limitations in the organisation, i.e. the effectiveness of the information flow in public finance sector units (ibid., pp. 94-108).

In 2016, the Polish Ministry of Finance conducted a questionnaire on the functioning of management control and internal auditing in local government units. Upon analysis of the 255 submitted forms, which constituted $44.7 \%$ of all the units which received the questionnaire form, certain issues referring to the improvement of the research fields of management control were obtained.

The author of the paper started the research in 2017 by distributing a questionnaire to 167 local government units. The aim of the research was to obtain information about the ways of management control performed in the analysed units. 81 units $(49 \%$ of the research population) answered the questionnaire by returning the form.

Internal auditors stated that the most frequent tools for assessment of management control were: self-assessment questionnaire, internal audit, benchmarking and the System of the Self-Government Analysis (Polish SAS). Over $85 \%$ of the respondents indicated that the assessment of management control is performed by self-assessment. $53 \%$ of the respondents indicated that the assessment of management control is performed once per year. The self-assessment questionnaire and internal audit were pointed to as the most frequent tools implemented during the process of management control assessment, which means that the selfassessment questionnaire is parallel with the internal audit, and both tools are implemented for the assessment of management control. The questionnaire results also indicate that $85 \%$ of local government units perform the assessment of management control with the implementation of self-assessment. Internal auditors (53\%) indicated that they perform the assessment of 
management control for the whole unit. This means that $47 \%$ of internal auditors perform the assessment of management control only within the framework of tasks which are included in the annual auditing plan. Table 1 demonstrates the results of the questionnaire.

Table 1.

Assessment of internal control in local government units

\begin{tabular}{|l|l|r|}
\hline Assessment of internal control & Specification & \multicolumn{1}{|c|}{$\begin{array}{c}\text { Percentage of } \\
\text { respondents } \\
\text { answers }\end{array}$} \\
\hline \multirow{4}{*}{$\begin{array}{l}\text { The most frequently applied instruments } \\
\text { of management control }\end{array}$} & Self-Assessment Questionnaire & 43.3 \\
\cline { 2 - 3 } & Internal audit & 40.0 \\
\cline { 2 - 3 } & Benchmarking & 13.3 \\
\cline { 2 - 3 } & $\begin{array}{l}\text { The System of Self-Government Analysis } \\
\text { (SAS)( Pl. System Analiz Samorządowych) }\end{array}$ & 3.3 \\
\hline \multirow{2}{*}{$\begin{array}{l}\text { Assessment of management control in } \\
\text { the form of self-assessment }\end{array}$} & Yes & 85.2 \\
\cline { 2 - 3 } & No & 9.9 \\
\cline { 2 - 3 } $\begin{array}{l}\text { Annual management control assessment } \\
\text { of the unit by an internal auditor }\end{array}$ & No data & 4.9 \\
\cline { 2 - 3 } & Yes & 53.1 \\
\hline
\end{tabular}

Source: own elaboration.

\section{Assessment of management control in the local government unit of the Municipal Office of $Z$}

Municipal Office of $Z$ performs tasks within the scope of management control on the basis of the Ordinance of the President of $Z$ city, regarding the organisational rules and functioning of the management control system (Ordinance of President $Y$ of March 10, 2015...). According to the above-mentioned Organise, the management control of the Municipal Office functions on two levels:

1. I level - control exercised by:

a) the President as the Head of the Office, implemented through the heads of departments,

b) supervisors of the local organisational units.

2. II level - control implemented at the level of organisational units of the city and supervised by the President of city (Ordinance of President Y of March 10, 2015..., p. 2).

- Monitoring the stage of implementation of goals and tasks in accordance with the adopted assumptions, as well as applying corrective measures if necessary;

- Obtaining reasonable assurance that the public expenditure are made:

- In a manner that is purposeful and cost-effective, pursuant to the rules of obtaining the best effects from the given input, optimal selection of methods, as well as resources available to achieve the intended goals,

- In a manner which enables the timely implementation of tasks, 
- In the amount and by dates which stem from previously incurred liabilities,

o According to the law,

- Assessment of the accuracy of implemented tasks.

The manners of implementation of monitoring and assessment of management control in the Municipal Office of $Z$ are presented in Table 2 of this paper.

Table 2.

Implementation of the field concerning the monitoring and assessment of management control - I level

\begin{tabular}{|c|c|}
\hline $\begin{array}{l}\text { Name of the internal } \\
\text { control standard }\end{array}$ & Implementation of the field of management control assessment in practice \\
\hline $\begin{array}{l}\text { Management control } \\
\text { monitoring }\end{array}$ & $\begin{array}{l}\text { The scope of monitoring involves: The assessment of the management control } \\
\text { system, including the system of risk management in the Municipal Office and } \\
\text { local organisational units, is undertaken in a continuous manner. The level of } \\
\text { identified risk and the efficacy of applied methods in order to limit it shall be } \\
\text { continually evaluated by the Heads of Departments and the supervisor of local } \\
\text { organisational units. The results of the assessment are implemented on an } \\
\text { ongoing basis with the purpose of increasing management control efficiency, as } \\
\text { well as improving the system thereof. By } 31 \text { January of each year, the Heads of } \\
\text { Departments and the supervisor of organisational units shall submit to the } \\
\text { President's Representative the information for the previous year regarding the } \\
\text { implementation of goals and activities, as well as the risks identified in the } \\
\text { previous year. In particular, the information submitted shall include the } \\
\text { assessment of the effectiveness of the adopted methods of risk prevention, as } \\
\text { well as the impact of those methods on the risk materiality level. }\end{array}$ \\
\hline $\begin{array}{l}\text { Self-assessment - It is } \\
\text { advisable to undertake, at } \\
\text { least twice a year, a self- } \\
\text { assessment of the } \\
\text { management control system } \\
\text { by supervisors and } \\
\text { employees of the unit. }\end{array}$ & $\begin{array}{l}\text { The self-assessment of the management control system allows the supervisor of } \\
\text { the unit to review the existing mechanisms of control in terms of effectiveness } \\
\text { and implementation of enhancements. Once a year, the Heads of Departments } \\
\text { and the supervisor of local organisational units shall undertake a self- } \\
\text { assessment of the management control system and prepare a report thereon. } \\
\text { The results of the self-assessment for the previous year are submitted to the } \\
\text { Representative by the end of February of each year. The Representative shall } \\
\text { analyse the accomplishments in reaching the standards of management control } \\
\text { in Municipal Offices and cities. }\end{array}$ \\
\hline $\begin{array}{l}\text { Internal audit } \\
\text { Under the terms and } \\
\text { conditions stipulated in the } \\
\text { Public Finance Act, the } \\
\text { auditor conducts an } \\
\text { objective and independent } \\
\text { assessment of management } \\
\text { control. }\end{array}$ & $\begin{array}{l}\text { The internal auditor operates in compliance with the Internal Audit Charter and } \\
\text { the Code of Ethics. In the Municipal Office, the activities of the internal auditor } \\
\text { are assigned to two persons employed under the internal audit unit, and they } \\
\text { report directly to the supervisor of the unit. The internal audit conducts activities } \\
\text { in compliance with the annual internal audit plan and undertakes the assessment } \\
\text { of management control in Municipal Offices and the reporting units thereof in } \\
\text { the course of performing audit duties. }\end{array}$ \\
\hline $\begin{array}{l}\text { Obtaining assurance about } \\
\text { the state of management } \\
\text { control is the result of the } \\
\text { following: } \\
\text { - monitoring, self- } \\
\text { assessment } \\
\text { audit and controls } \\
\text { executed. }\end{array}$ & $\begin{array}{l}\text { No later than } 15 \text { April, the Representative submits to the President of the city } \\
\text { the report on the state of management control in the Municipal Office, together } \\
\text { with the proposals for enhancements in the event of unsatisfactory } \\
\text { implementation of the management control standards. Thus, reports on the } \\
\text { implementation of goals and activities shall be likewise submitted. } \\
\text { By the end of February of the year, the supervisor of local organisational units } \\
\text { shall submit declarations on the state of management control in the subordinate } \\
\text { organisational units, which are stipulated in the Regulation of the President of } \\
\text { the city as regards the rules of organisation and functioning of management } \\
\text { control in the Municipal Office of } Z \text {. }\end{array}$ \\
\hline
\end{tabular}

Source: own study.

Close observation of the functioning of management control, and thus the assessment and monitoring in the Municipal District of $\mathrm{Z}$, leads to the conclusion that the units possess procedures regarding management control, its assessment and risk estimation. However, 
it might be assumed that formal documents and further procedures in the scope of management control lead to a clearly procedural manner of fulfilment of duties by employees.

In the Municipal District of $Z$, the management control representative, once a year, presents the assessment of management control, which shall include: the results of the self-assessment, risk analysis, benchmarking, internal audit, as well as the report on internal and external controls. Due to limited staff resources, two internal auditors fulfil the duties in the Municipal District of $Z$ and the subordinate units. Such a solution indicates that a vast majority of the activities of an audit come down to the evaluation of a particular area of management control. Furthermore, one may observe a lack of an integrated method of assessment of management control.

\section{Application of integrated assessment of management control in the Municipal District of $\mathbf{Z}$}

In the first stages, the author of this paper reviewed the applied instruments used in the assessment of management control in the Municipal District of $Z$ and conducted their evaluation, as presented in Table 3 .

Table 3.

Strengths and weaknesses of the applied instruments of management control in the Municipal District of $Z$

\begin{tabular}{|c|c|c|c|}
\hline $\begin{array}{c}\text { Instruments of } \\
\text { management } \\
\text { control } \\
\text { assessment }\end{array}$ & Strengths & Weaknesses & Remarks \\
\hline \multirow[t]{2}{*}{$\begin{array}{c}\text { Self-assessment } \\
\text { of management } \\
\text { control }\end{array}$} & $\begin{array}{l}\text { A self-assessment questionnaire } \\
\text { is completed by the } \\
\text { organisational units of the } \\
\text { Municipal Office and } \\
\text { subordinate units. It is } \\
\text { implemented in compliance } \\
\text { with the provisions of the law. }\end{array}$ & \multirow[t]{2}{*}{$\begin{array}{l}\text { The absence of a standardised } \\
\text { Information Technology tool } \\
\text { for all of the Municipal Office } \\
\text { units and the organisational } \\
\text { units of the city. }\end{array}$} & \multirow[t]{2}{*}{$\begin{array}{l}\text { Additional costs - } \\
\text { purchase of IT } \\
\text { tools. } \\
\text { Undertaken in the } \\
\text { Municipal Office } \\
\text { and subordinate } \\
\text { units. }\end{array}$} \\
\hline & $\begin{array}{l}\text { Completing the declaration of } \\
\text { the state of management control } \\
\text { in the Municipal Office and } \\
\text { subordinate units. }\end{array}$ & & \\
\hline ISO - 9001 & $\begin{array}{l}\text { Receiving the certificate of } \\
\text { quality. }\end{array}$ & $\begin{array}{l}\text { Failure in adjusting ISO to the } \\
\text { requirements of the Ministry } \\
\text { of Finance in the scope of } \\
\text { management control. }\end{array}$ & $\begin{array}{l}\text { Additional costs } \\
\text { related to the } \\
\text { certification, } \\
\text { involvement of the } \\
\text { people assigned to } \\
\text { conduct the ISO } \\
\text { audit during } \\
\text { working hours. The } \\
\text { instrument does not } \\
\text { occur in the } \\
\text { subordinate units. }\end{array}$ \\
\hline
\end{tabular}


Cont. table 3.

\begin{tabular}{|c|c|c|c|}
\hline Internal Audit & $\begin{array}{l}\text { It assesses management control } \\
\text { within the framework of } \\
\text { adequacy, effectiveness and } \\
\text { efficiency. }\end{array}$ & $\begin{array}{l}\text { It assesses the management } \\
\text { control only within the } \\
\text { framework of a given task and } \\
\text { does not conduct an integrated } \\
\text { assessment of management } \\
\text { control. }\end{array}$ & $\begin{array}{l}\text { Statutory } \\
\text { requirement. }\end{array}$ \\
\hline \multirow{6}{*}{ Benchmarking } & \multirow[t]{6}{*}{$\begin{array}{l}\text { Possibility to compare different } \\
\text { local government units. }\end{array}$} & $\begin{array}{l}\text { The absence of information } \\
\text { about the means of using the } \\
\text { data gathered the by } \\
\text { management of the Municipal } \\
\text { Office and the subordinate } \\
\text { units. }\end{array}$ & $\begin{array}{l}\text { A lack of support } \\
\text { to the supervisors } \\
\text { of the } \\
\text { organisational } \\
\text { units in } \\
\text { completing the } \\
\text { data. } \\
\text { The instrument } \\
\text { does not occur in } \\
\text { the subordinate } \\
\text { units. }\end{array}$ \\
\hline & & $\begin{array}{l}\text { Intense involvement in } \\
\text { reporting by the employees of } \\
\text { the Municipal Office and } \\
\text { organisational units. }\end{array}$ & \multirow{5}{*}{$\begin{array}{l}\text { Additional } \\
\text { involvement in } \\
\text { completing the } \\
\text { data by people in } \\
\text { the Municipal } \\
\text { Office and } \\
\text { organisational } \\
\text { units. }\end{array}$} \\
\hline & & $\begin{array}{l}\text { The absence of IT tools } \\
\text { utilised to conduct specialised } \\
\text { comparative analyses. }\end{array}$ & \\
\hline & & $\begin{array}{l}\text { Heads of Departments do not } \\
\text { have influence on determining } \\
\text { a given indicator. The } \\
\text { indicator as such is acquired in } \\
\text { Benchmarking. }\end{array}$ & \\
\hline & & $\begin{array}{l}\text { Comparative Analysis requires } \\
\text { obtaining additional data. }\end{array}$ & \\
\hline & & $\begin{array}{l}\text { Currently, there are } 12 \text { units of } \\
\text { the Municipal Office involved } \\
\text { in Benchmarking, and they } \\
\text { answer } 189 \text { questions. }\end{array}$ & \\
\hline \multirow{4}{*}{$\begin{array}{c}\text { SAS - } \\
\text { The System of } \\
\text { Self-Government } \\
\text { Analysis }\end{array}$} & \multirow{2}{*}{$\begin{array}{l}\text { Monitoring of public services in } \\
\text { cities by the use of a very good } \\
\text { analytical IT tool which would } \\
\text { enable assessing the input, } \\
\text { effectiveness and impact of } \\
\text { services. }\end{array}$} & $\begin{array}{l}\text { The absence of information } \\
\text { about the means of using the } \\
\text { data gathered. }\end{array}$ & \multirow{4}{*}{$\begin{array}{l}\text { Additional } \\
\text { involvement in } \\
\text { completing the } \\
\text { data by people in } \\
\text { the Municipal } \\
\text { Office and } \\
\text { organisational } \\
\text { units. }\end{array}$} \\
\hline & & $\begin{array}{l}\text { Strong involvement in } \\
\text { reporting by employees of the } \\
\text { Municipal Office and the } \\
\text { organisational units. }\end{array}$ & \\
\hline & \multirow{2}{*}{$\begin{array}{l}\text { The second best instrument in } \\
\text { Europe, after the Norwegian } \\
\text { instrument, according to the } \\
\text { Association of Polish Cities. }\end{array}$} & $\begin{array}{l}\text { Heads of Departments do not } \\
\text { have influence on determining } \\
\text { a given standard. }\end{array}$ & \\
\hline & & $\begin{array}{l}\text { Currently, in the system of } \\
\text { Self-Government Analysis } \\
\text { (SAS), there are } 5 \text { units of the } \\
\text { Municipal Office which } \\
\text { answer } 380 \text { questions. }\end{array}$ & \\
\hline \multirow{3}{*}{ Reporting } & $\begin{array}{l}\text { Current analysis in selected } \\
\text { aspects of activities of the local } \\
\text { Municipal Office. }\end{array}$ & $\begin{array}{l}\text { A large number of reports } \\
\text { submitted to particular units. }\end{array}$ & \multirow{3}{*}{$\begin{array}{l}\text { Additional } \\
\text { involvement in } \\
\text { completing the } \\
\text { data by people in } \\
\text { the Municipal } \\
\text { Office and } \\
\text { organisational } \\
\text { units. }\end{array}$} \\
\hline & Possibility to make comparisons. & $\begin{array}{l}\text { Information provided in } \\
\text { different reports might be } \\
\text { duplicated. }\end{array}$ & \\
\hline & $\begin{array}{l}\text { The units gathering particular } \\
\text { reports conduct their current } \\
\text { analysis. }\end{array}$ & $\begin{array}{l}\text { Frequency and the form of } \\
\text { provided information; not all } \\
\text { of the reports are provided in } \\
\text { an electronic form. }\end{array}$ & \\
\hline
\end{tabular}


Cont. table 3.

\begin{tabular}{|c|l|l|l|}
\hline Strategy & $\begin{array}{l}\text { Preparation of a professional IT } \\
\text { tool to conduct the current } \\
\text { analysis of strategic tasks. } \\
\text { Possibility of correlation with } \\
\text { management control based on } \\
\text { legal grounds. }\end{array}$ & $\begin{array}{l}\text { The absence of IT tools } \\
\text { integrated with goals and } \\
\text { operational tasks. }\end{array}$ & $\begin{array}{l}\text { The cost of IT } \\
\text { tool } \\
\text { implementation. }\end{array}$ \\
\hline
\end{tabular}

Source: own study.

In the consecutive stages of evaluation, the author gathers and analyses the data acquired from the instruments presented in Table 4.

Table 4.

Analysis of the quantity of data from the assessment of management control in the Municipal Office of $Z$ - concerning the instruments of management control assessment enumerated in Table 3

\begin{tabular}{|c|c|c|c|c|c|c|}
\hline Name & $\begin{array}{l}\text { Management } \\
\text { control }\end{array}$ & ISO & Benchmarking & SAS & $\begin{array}{c}\text { City } \\
\text { development } \\
\text { strategy }\end{array}$ & Sum \\
\hline $\begin{array}{l}\text { The number of } \\
\text { organisational units of } \\
\text { the Municipal Office } \\
\text { which are obliged to } \\
\text { provide information to } \\
\text { particular instruments of } \\
\text { management control } \\
\text { assessment }\end{array}$ & 31 & 31 & 12 & 10 & 14 & 98 \\
\hline The number of indicators & 263 & 242 & 0 & 0 & 44 & 549 \\
\hline $\begin{array}{l}\text { The number of tasks/ } \\
\text { processes }\end{array}$ & 127 & 158 & 0 & 0 & 104 & 389 \\
\hline Number of goals/ tasks & 83 & 158 & 0 & 0 & 104 & 345 \\
\hline $\begin{array}{l}\text { Number of identified } \\
\text { risks }\end{array}$ & 250 & 0 & 0 & 0 & 227 & 477 \\
\hline $\begin{array}{l}\text { Legal requirement of } \\
\text { management control } \\
\text { instrument }\end{array}$ & $\begin{array}{l}\text { Yes - the } \\
\text { public finance } \\
\text { act }\end{array}$ & No & No & No & $\begin{array}{c}\text { Yes - } \\
\text { Municipal } \\
\text { Office } \\
\text { resolution }\end{array}$ & - \\
\hline $\begin{array}{l}\text { Frequency of provided } \\
\text { information in a year }\end{array}$ & 4 times & 4 times & 2 times & 1 time & 4 times & 15 \\
\hline
\end{tabular}

Source: own study.

The analysis of the data identified 549 indicators in a proportion of 345 goals and 389 tasks in the Municipal District. The indicators are listed from various sources of information.

The analysis shows that in a vast majority, the indicators in the Municipal District of $Z$ are duplicated, and thus they are counted two times. Therefore, the supervisor of the unit might not receive reliable information regarding the management of the unit, or the provided information is not significant. To be precise, the mentioned information concerns the first level of management control in the Municipal Office and not the second level, namely the organisational units.

On the basis of the presented model of the integrated assessment of management control, the author has conducted an assessment in the Municipal District of $Z$. The table below presents the findings. 
Table 5.

Integrated assessment of management control - I level

\begin{tabular}{|c|c|c|c|c|}
\hline \multicolumn{5}{|c|}{ Strategic management - determining mission, vision, goals and tasks } \\
\hline Strategic goals & Strategic tasks & $\begin{array}{l}\text { Stage of } \\
\text { implementation of } \\
\text { strategic tasks }\end{array}$ & $\begin{array}{l}\text { Risk in the } \\
\text { implementation of a } \\
\text { strategic plan }\end{array}$ & $\begin{array}{l}\text { Activities after } \\
\text { implementation of } \\
\text { strategic tasks }\end{array}$ \\
\hline $\begin{array}{l}\text { Ensuring } \\
\text { implementation } \\
\text { of investment } \\
\text { tasks in the } \\
\text { Municipal } \\
\text { District }\end{array}$ & $\begin{array}{l}\text { Thermal } \\
\text { efficiency } \\
\text { improvement of } \\
\text { educational } \\
\text { institutions }\end{array}$ & $\begin{array}{l}\text { The indicator of the } \\
\text { implementation of } \\
\text { investments in the } \\
\text { annual period; } \\
\text { according to the work } \\
\text { schedule }-50 \%\end{array}$ & $\begin{array}{l}\text { 1. Delays in the } \\
\text { implementation of } \\
\text { particular stages of } \\
\text { works or in the } \\
\text { schedule items. } \\
\text { 2. Exceeding planned } \\
\text { expenses } \\
\text { 3. Identifying faults in } \\
\text { the final acceptance } \\
\text { of works }\end{array}$ & $\begin{array}{l}\text { Securing financial } \\
\text { resources for } \\
\text { implementation of } \\
\text { the tasks } \\
\text { Regular monitoring } \\
\text { of implemented } \\
\text { works }\end{array}$ \\
\hline \multicolumn{5}{|c|}{ Operational management - determining mission, vision, goals and tasks - related to strategic goals } \\
\hline 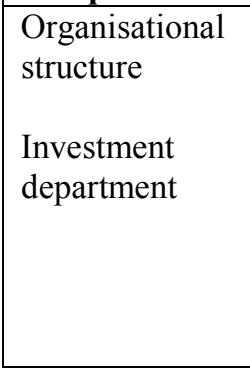 & $\begin{array}{l}\text { Operational } \\
\text { tasks } \\
\text { Thermal } \\
\text { efficiency } \\
\text { improvement of } \\
3 \text { educational } \\
\text { institutions }\end{array}$ & $\begin{array}{l}\text { Stage of } \\
\text { Implementation of } \\
\text { operational tasks } \\
\text { The number of } \\
\text { executed } \\
\text { modernisations } \\
\text { compared to those } \\
\text { planned: } 30 \%\end{array}$ & $\begin{array}{l}\text { Operational tasks risk } \\
\text { analysis } \\
\text { Delays in the } \\
\text { implementation of } \\
\text { particular stages of } \\
\text { works }\end{array}$ & $\begin{array}{l}\text { Activities after } \\
\text { implementation of } \\
\text { operational tasks } \\
\text { Withdrawal from } \\
\text { the completion of } \\
\text { an agreement and } \\
\text { entering into a new } \\
\text { agreement with } \\
\text { another contractor }\end{array}$ \\
\hline
\end{tabular}

Source: own study.

Table 7.

Integrated assessment of management control. II level of management control - organisational units of the Municipal District - educational facilities

Operational management determining mission, vision, goals and tasks - related to strategic goals

\begin{tabular}{|l|l|l|l|l|}
$\begin{array}{l}\text { Organisational } \\
\text { structure }\end{array}$ & Operational tasks & $\begin{array}{l}\text { Stage of } \\
\text { implementation of } \\
\text { operational tasks }\end{array}$ & $\begin{array}{l}\text { Risk analysis of } \\
\text { operational tasks }\end{array}$ & $\begin{array}{l}\text { Activities after } \\
\text { implementation of } \\
\text { operational tasks }\end{array}$ \\
$\begin{array}{l}\text { Educational } \\
\text { facilities } \mathrm{x}, \mathrm{y}, \mathrm{z}\end{array}$ & $\begin{array}{l}\text { Ensuring conditions } \\
\text { for the proper } \\
\text { functioning of a } \\
\text { facility by means of } \\
\text { thermal efficiency } \\
\text { improvement }\end{array}$ & $\begin{array}{l}\text { Thermal efficiency } \\
\text { improvement } \\
\text { accomplished only }\end{array}$ & $\begin{array}{l}\text { In winter, facilities y } \\
\text { and z will not be able } \\
\text { to conduct school } \\
\text { lessons due to the low } \\
\text { temperature in rooms }\end{array}$ & $\begin{array}{l}\text { Securing expenses } \\
\text { for additional } \\
\text { heating during the } \\
\text { winter period }\end{array}$ \\
\hline
\end{tabular}

Source: own study.

\section{Conclusion}

Advantages of applying the model of integrated assessment of management control:

1. Possibility to assess the management control of the local government units, as well as their subordinate units, in all areas of management.

2. Increasing the awareness and responsibility of the supervisors and employees for the functioning of management control. 
3. Prompt acquisition of data concerning the stage of implementation of the goals and tasks. Furthermore, analysis of data in order to undertake necessary management initiatives.

4. Minimisation of the time and costs of gathering data, as well as indicators from particular instruments of management control assessment.

5. Standard method of the management control assessment in local government units.

6. The indicators of the implementation of tasks are not duplicated, and thus it is not necessary to analyse the same areas repeatedly.

\section{References}

1. Bielińska-Dusza, E. (2011). Audyt wewnętrzny w ocenie badań empirycznych to rozdział 2.3. In: M. Lisiński (ed.), Audyt wewnętrzny w doskonaleniu instytucji. Aspekty teoretycznometodologiczne i praktyczne. Warszawa: PWE.

2. Cangemi, M.P., Singleton, T. (2003). Managing the Audit Function-A Corporate Audit Department Procedures Guide. Chapter 3: Internal Control System Effective Internal Control Models. New Jersey: John Wiley \& Sons, Inc.

3. Cushman, D.P., King, S.S. (1995). Communication and High Speed Management. New York: State University of New York Press.

4. Czyżak, R., Czyżak, M. (2003). Kontrola w administracji publicznej-istota, cele i rodzaje. Kwartalnik Prawa Publicznego, Nr. 4.

5. Dobrowolski, Z. (2017). Prolegomena epistemologii oraz metodologii kontroli zarzadczej. Krakowie: Monografie i Studia Instytutu Spraw Publicznych Uniwersytetu Jagiellońskiego.

6. Dyczkowska, J., Dyczkowski, T. Organizacja kontroli zarządczej w jednostkach sektora publicznego - wyniki badań empirycznych. Prace Naukowe Uniwersytetu Wrocławskiego, Rachunkowość i Contorling, Nr 344.

7. Gawroński, H. (2010). Zarządzanie strategiczne w samorządach lokalnych. Warszawa: Wolters Kluwer Polska.

8. Kieżun, W. (1998). Sprawne zarządzanie organizacjami. Warszawa.

9. Klim, M. (2018). Praktyczne aspekty budowania systemu kontroli zarządczej w niewielkich gminach. Zeszyty UE.

10. Kline, R.B. (2016). Principles and practice of structural equation modeling. New York: The Guilford Press. 
11. Komunikat Ministerstwa Finansów Nr 23 z dnia 16 grudnia 2009 r. w sprawie Standarów kontroli zarządczej dla jednostek sektora finansów publicznych (Dz. Urz. Nr 23, poz. 84 z 2009 r.).

12. Komunikat Ministra Rozwoju i Finansów z dnia 12 grudnia 2016 r. w sprawie standardów audytu wewnętrznego (Dz. Urz., poz. 28).

13. Komunikat Nr 23 Ministra Finansów z dnia 16 grudnia 2009 r. w sprawie standardów kontroli zarządczej dla sektora finansów publicznych (Dz. Urz. Min. Fin. Nr 15, poz. 84).

14. Komunikat Nr 3 Ministra Finansów z dnia 16 lutego 2011 r. w sprawie szczegółowych wytycznych w zakresie samooceny kontroli zarządczej dla jednostek sektora finansów publicznych (Dz. Urz. Min. Fin. Nr 2, poz. 11).

15. Komunikat Nr 6 Ministra Finansów z dnia 6 grudnia 2012 r. w sprawie szczegółowych wytycznych dla sektora finansów publicznych w zakresie planowania i zarządzania ryzykiem(Dz. Urz. Min. Fin. poz. 56).

16. Komunikat Nr 6 Ministra Rozwoju i Finansów z dnia 6 grudnia 2012 r. w sprawie szczegółowych wytycznych dla sektora finansów publicznych $\mathrm{w}$ zakresie kontroli zarządczej w zakresie planowania i zarządzania ryzykiem (Dz. Urz. z 2012 roku, poz.56).

17. Kontrola zarządcza w sektorze finansów publicznych. Istota, unormowania prawne i otoczenie. Kompendium wiedzy (wersja 1.0). Ministerstwo Finansów.

18. Krasodomska, J. (2012). Zintegrowana sprawozdawczość spółek w 2020 roku. Zeszyty Teoretyczne Rachunkowości, 2, Nr 66(122).

19. Lisiecka, K. (2012). Audyt wewnętrzny i kontrola zarzadcza w procesach doskonalenia zarzadzania organizacja sektora publicznego. Seminaryjne posiedzenie Kolegium Najwyższej Izby Kontroli, 5.12.2012, https://www.nik.gov.pl/kolegium-nik/posiedzenia/ seminaryjne-posiedzenie-kolegium-nik.html.

20. Louwers, T.J., Ramsay, R.J., Sinason, D.H., Strawser, J.R. (2005). Auditing \& Assurance Services. New York: McGraw-Hill/Irwin, International Edition.

21. Marcinkowski, L. (2011). Kontrola zarządcza - polemika. Kontrola Państwowa 2010, Nr 6, p. $106 \&$ n.

22. Szostak, R. (2011). Na czym polega kontrola zarządcza. Kontrola Państwowa, Nr 1

23. Ocena funkcjonowania kontroli zarzadczej $i$ prowadzenia audytu wewnętrznego w jednostkach samorządu terytorialnego (2016). Warszawa: Ministerstwo Finansów, 12.08.2019.

24. Mituś, A. (2017). Wybrane zagadnienia z zakresu kontroli zarządczej w jednostkach samorządu terytorialnego. Zarządzanie Publiczne, Nr 3. Kraków: UE. 
25. Moore, M.H. (1995). Creating public value: Strategic management in government. Cambridge, MA: Harvard University Press.

26. Informacja o wynikach kontroli funkcjonowania kontroli zarządczej $w$ jednostkach samorząu terytorialnego ze szczególnym uwzględnieniem audytu wewnętrznego (2011a). LGD-4101-036/2011. Najwyższa Izba Kontroli, 11.08.2017.

27. Nowak, E. (2003). Zawansowana rachunkowość zarzadcza. Warszawa: PWE.

28. Obwieszczenie Ministra Finansów z dnia 22 lutego 2018 r. w sprawie ogłoszenia jednolitego tekstu rozporządzenia Ministra Finansów w sprawie audytu wewnętrznego oraz informacji o pracy wynikach tego audytu (Dz.U. z 2018 r., poz. 506).

29. Pablo, A., Reay, T., Dewald, J.R., \& Casebeer, A. (2007). Identifying, enabling and managing dynamic capabilities in the public sector. Journal of Management Studies.

30. Paliga, E. (2015). System kontroli zarządczej w praktyce polskiej administracji publicznej. Ekonomika i Organizacja Przedsiębiorstwa. Orgmasz.

31. Remlein, M. (2015). Doświadczenia polskich grup kapitałowych w zakresie zintegrowanej sprawozdawczości. Studia Oeconomica Posnaniensia, Nr 3(1).

32. Sławińska-Tomtała, E. (2011). Zarządzenie w sprawie systemu kontroli zarządczej. In: E. Sławińska-Tomtała (ed), Teczka kontroli zarzadczej $w$ jednostkach sektora publicznego. Wzory dokumentów z wyjaśnieniami. Wydawnictwo C.H. Beck (Beck InfoBiznes).

33. Sola, M. (2009). Kontrola zarzadcza w administracji samorzadowej. Warszawa: Manicipium.

34. Szpor, A. Pojęcie kontroli zarzadczej (wybrane aspekty). http://www.mf.gov.pl/c/ document_library/get_file?uuid=b43e6d5f-4c5e-42db-b7cb-1251fd16a308\&groupId= 764034, 10.01.2020.

35. Ustawa z dnia 27 sierpnia 2009 r. o finansach publicznych (t.j. Dz.U. z 2019 r., poz. 869, z późn. zm.).

36. Walker, R.M. (2016). Innovation type and diffusion: An empirical analysis of local government. Public Administration, 84, 311-335.

37. Williamson, O.E. (2985). The Economic Institutions of Capitpalism. New York: Free Press.

38. Zarządzenie Prezydenta Y z dnia 10 marca 2015 roku w sprawie zasad organizacji i funkcjonowania systemu kontroli zarządczej w Mieście Y, 01.10.2019. 